\title{
HEIDEGGER A HUSSERL O ČASE
}

\section{Jürgen Stolzenberg}

Když v roce 1928 vydal Martin Heidegger - krátce po vydání Bytí a času - Husserlovy göttingenské přednášky ze zimního semestru 1904/1905 k Fenomenologii vnitřního časového vědomí v X. svazku Jahrbuch für Philosophie und phänomenologische Forschung, nebylo to jen výrazem úcty a gestem vděku vůči svému učiteli, ale také věcí jeho vlastního zájmu. Uveřejnění Husserlových přednášek př́ihodně upozornilo na Heideggerovo nové založení fenomenologie v Bytí a času a vyjevilo distanci vůči Husserlovu fenomenologickému výzkumnému programu. Čtenáři „Předmluvy vydavatele“ mohla stěží uniknout poznámka, že výraz „intencionalita“ „není ani dnes řešením, nýbrž označením ústředního problému“". Heidegger byl o sobě přesvědčen, že ve zpracování tohoto problému postoupil o výrazný kus dále než jeho učitel, a tuto skutečnost se snažil zdokumentovat Bytím a časem.

Heidegger zformuloval již dřive ve Freiburku, Husserlem zjevně nezpozorován, filosofický program, který proti Husserlovým snahám o metodicky a věcně přiměřený fenomenologický popis kognitivních funkcí a jejich vztahu ke světu postavil teorii konkrétní subjektivity, jejímž předmětem není skutečnost vědomí, nýbrž všem objektivacím předcházející vztah ke světu, jehož analýzy měly poskytnout základ pro zcela nově pojatou ,fenomenologickou“ teorii subjektivity. Časovost, jak zní Heideggerův termín používaný v Bytí a času, není částí fenomenologicky vykazatelné intencionální skutečnosti vědomí, nýbrž základním ustrojením hermeneuticko-praktického vztahu subjektu ke světu, přičemž subjekt, který Heidegger, jak známo, označuje jako pobyt, se v tomto vztahu význačným způsobem vztahuje k sobě.

Lze vycházet z toho, že Heidegger byl s Husserlovými vlastními neutuchajícími zkoumáními času obeznámen doslova z první ruky: svému geniálnímu, a jak se domníval, také věrnému žákovi přenechal Husserl

1 M. Heidegger, Vorwort des Herausgebers, in: E. Husserl, Vorlesungen zur Phänomenologie des inneren Zeitbewußtseins, vyd. M. Heidegger (Jahrbuch für Philosophie und phänomenologische Forschung, IX), Halle 1928, str. 367. 
své pracovní rukopisy $\mathrm{k}$ tomuto tématu ke studiu. ${ }^{2}$ Můžeme snad vycházet i z toho, že tyto rukopisy obsahovaly mj. také úvahy o času, jež Husserl rozvinul na základě svého projektu založení čisté, resp. transcendentální fenomenologie, který realizoval ještě v pozdním göttingenském období.

Jedním z nejdůležitějších Husserlových sebekritických bodů je, jak známo, zavedení konceptu čistého Já. Vědomí není popsáno adekvátně, pokud je chápeme, jak Husserl říká v Logických zkoumáních, pouze jako „celkovou reelní fenomenologickou skutečnost empirického Já“ a jako „vpletení psychických prožitků do jednoty prožitkového proudu“; ${ }^{3}$ vědomí je bytostně vztahem prožitků k subjektu, jenž je od nich odlišný a jenž je jakožto ,čisté Já“ invariantním centrem všech prožitků a intencionálních vztahů. To platí také pro strukturu vnitřního časového vědomí. Časové prožívání předpokládá vztah prožitků k čistému Já. ${ }^{4}$ Proti Husserlovu rekursu k čistému Já namítal Heidegger od samého začátku, že jde o konstrukci, která je odcizená fenoménům. To jednoznačně dokládají rané freiburské přednášky. ${ }^{5}$ Teorie časovosti, kterou Heidegger předložil v Bytí a času, není tedy věcně namířena jen proti Husserlově rané teorii času, jak se s ní setkáváme v göttingenských přednáškách z let 1904/1905. Je namířena také a ještě více proti koncepci, kterou Husserl představil veřejnosti ve svých Idejich k čisté fenomenologii a fenomenologické filosofii, a jejím časově-teoretickým implikacím.

Ve studii s názvem Heidegger a Husserl o času budeme na základě strukturálně-analyticky orientovaného srovnání sledovat otázku, jak je v obou teoretických kontextech zdůvodněn vztah subjektivity a časovosti. Díky tomu budeme moci nakonec zhodnotit Heideggerovu kritiku Husserla. Nejprve se obrátíme k Heideggerově teorii časovosti.

2 M. Heidegger, Bytí a čas, přel. I. Chvatík - M. Petříček - P. Kouba - J. Němec, Praha 2002, str. 56.

3 E. Husserl, Logische Untersuchungen: Untersuchungen zur Phänomenologie und Theorie der Erkenntnis (Husserliana, XIX/1), Den Haag 1984, str. 356.

4 E. Husserl, Ideje $k$ čisté fenomenologii a fenomenologické filosofii, přel. A. Rettová - P. Urban, Praha 2004, str. 167, 170.

5 M. Heidegger, Der Begriff der Zeit, vyd. F.-W. von Herrmann, in: Gesamtausgabe, LXIV, Frankfurt a. M. 2004. 


\section{Heideggerova teorie časovosti}

Teorii časovosti připsal Heidegger fundamentální zakládající funkci. Časovost má být posledním základem, z něhož lze dostatečně pochopit bytostné strukturní momenty takového vztahování se ke světu, pro něž Heidegger užívá termín „starost“. Ke koncepci starosti patří známé rozlišení dvou životních způsobů, tzv. neautentického životního způsobu ono se a životního způsobu autentické existence. Jak je rovněž dostatečně známo, první životní způsob je charakterizován tím, že Já ${ }^{6}$ orientuje svůj životní rozvrh nereflektovaně podle měřítka předem daných a kolektivně sdílených konvencí; tento životní způsob je primární a převládající. Naopak druhému životnímu způsobu leží v základu autentické rozhodnutí o tom, jak někdo chce žít a čím chce být. Postoj, který leží v základu sobě samému se zodpovídajícího životního rozvrhu, označuje Heidegger jako „odhodlanost k nejvlastnějšímu význačnému ,moci být'““.7 Tato odhodlanost se zakládá na teorii svědomí, ke které se ještě vrátíme.

Nyní je důležité si uvědomit, že Heidegger získává koncept časovosti z přesného popisu charakteru rozvrhu, jenž je implikován v oné „odhodlanosti k nejvlastnějšímu význačnému ,moci být'““. Odhodlanost je charakterizována jako „předběhová odhodlanost“" ${ }^{8}$ Řeč o předběhové odhodlanosti plyne z toho, co Heidegger nazývá jako bytí nebo predběh k smrti. Tím je míněno, že smrt je fenoménem, k němuž se máme vztahovat $\mathrm{v}$ rozvrhu svého života. Za prvé se $\mathrm{k}$ němu máme vztahovat a tento vztah uskutečňovat tak, že smrt je nezastupitelná. Z perspektivy vždy vlastní smrti vystupuje život ze všech odcizujících vztahů a soustřed'uje se jen na sebe. Potud je člověk nakonec se svým životem sám. Za druhé, a to je rozhodující moment, klepe smrt takříkajíc zpětně na personální život, nebot' pro svůj život hledáme nebo rozvrhujeme smysl pouze tehdy, je-li předznamenán konečností. Tak je rozvrh života vztažen vždy ke svému konci, a tím předchůdně $\mathrm{k}$ celku. V tomto smyslu se mluví o bytí či předběhu k smrti.

Tím však rozvrhový charakter personálního života ještě není adekvátně zohledněn. Realizovat personální životní rozvrh znamená realizovat vždy vlastní možnosti, abychom, jak se také ř́íká, přišli zpět $k$ sobě. Aby vyjádřil v tom obsažený procesuální charakter a specifický sebevztah tohoto druhu intencionality, mluví Heidegger nejprve poněkud iritujícím

\footnotetext{
6 „Já“ zde užíváme jako překlad pro výraz Selbst. - Pozn. překl.

7 M. Heidegger, Bytí a čas, str. 364.

8 Tamt.
} 
způsobem o „nechání sebe přicházet k sobě“. 9 Tím není míněna psychologie ponechanosti vůči nevypočitatelnému poměru úspěchu a nezdaru. Míněn je ten aspekt, že v rozvrhu životní perspektivy a její realizace je sice obsažena intencionalita vztažená k budoucímu bytí, avšak její jakoby centrifugální směr je třeba doplnit směrem opačným. Realizace životního rozvrhu představuje proces, v němž do budoucnosti směřující rozvrh nabývá $\mathrm{v}$ narůstající míře takřkka individuální podoby, konkretizuje se, a tímto způsobem se ztotožňuje s tou podobou, ve které, jak lze také rríci, přichází k sobě. Sebevztah implikovaný v tomto procesu se Heidegger pokouší vyjádřit v následující formulaci: pobyt v průběhu realizace svého životního rozvrhu nechává „,sebe přicházet k sobě“. To, rríká Heidegger, je ,původní fenomén přištího, budoucnosti“ ${ }^{10}$

Zároveň je třeba zohlednit ontologický status personálního života. Tento status je poznamenán neredukovatelnou fakticitou, kterou, řečeno s Hölderlinem, je třeba držet jako na ramenou nesenou zátěž ztroskotání. Fakticita je souhrnem toho, co již vždy bylo, k němuž se personální život musí vztahovat ve svém průběhu orientovaném na budoucnost. Jde o, jak zní Heideggerův obrat, ,rozumějící přicházení pobytu zpět k tomu, jak už vždy nejvlastněji byl“". ${ }^{11}$ Tím je v jednotě s první vykázána druhá forma intencionálního sebevztahu, kterou Heidegger interpretuje jako existenciální modus minulosti.

Třetí aspekt časovosti se týká aktuální př́itomnosti a herních prostorů jednání, které otevírá. V ní se konkretizuje životní rozvrh. Vzhledem ke vždy přítomným situacím je, jak říká Heidegger, „u sebe“. Přítomnost, pojatá Heideggerem rovněž v procesuálním smyslu jako ,zpřítomňování“, ${ }^{12}$ je třetí formou časově se realizujícího sebevztahu pobytu. Jednotu těchto tří dimenzí nazývá Heidegger ,časovost“. ${ }^{13}$

Tato struktura časovosti je vztažena $\mathrm{k}$ teorii autenticity existence. To znamená: jednota tř́ časových dimenzí je teoretickým fundamentem, z něhož má být pochopen způsob, jak se personální životní rozvrh realizuje v modu autenticity. Abychom mohli adekvátně pochopit a posoudit systematickou funkci teorie časovosti, musíme si vyjasnit Heideggerovu teorii autenticity existence.

\footnotetext{
9 Tamt.

10 Tamt.

11 Tamt., str. 365.

12 Tamt.

13 Tamt., str. 366.
} 


\section{Heideggerova teorie autenticity existence}

Teorie autenticity je odpovědí na otázku, jak individuální Já, jež je ztraceno ve světě kolektivního ono se, je s to odhalit svou svobodu, a to znamená, jak je s to chápat samo sebe jako důvod a účel svého životního rozvrhu. To není schopno vykonat z vlastního popudu. Spíše mu to musí ukázat nějaká vnější instance. Má se tak stát ve formě jemu adresovaného apelu, výzvy, kterou Heidegger nazývá volání svědomí. Je třeba se ptát, jak lze takovou výzvu pochopit a realizovat.

Má-li Já to, co mu má toto volání rríci, nejen vnímat, ale také pochopit, a tím vztáhnout $\mathrm{k}$ sobě, pak musí již být zajištěno následující: musí si, za prvé, udržovat distanci od svých primárních vztahů ke světu, jež tvoří svět onoho ono se, a za druhé se musí v této distanci moci vztahovat k sobě. Konečně, a to je rozhodující, se při tom musí chápat pozitivně jako bytost, jež se může rozhodovat a určovat sama ze sebe, nezávisle na svých primárních vztazích ke světu, a podle tohoto určení jednat. Takovéto sebevědomí, které předchází všem konkrétním vztahům ke světu, sebevědomí dispozicionální a praktické, je třeba předpokládat jako adresáta výzvy. Lze nyní ríci, že se na základě této výzvy osvobozuje z pouze implicitního postoje - z ,útočiště“ (Unterkunft) a ze svého „úkrytu“ (Versteck), ${ }^{14}$ jak se Heidegger obrazně vyjadřuje -, který zaujímá v modu onoho ono se, a je přivedeno k sobě samému. Že je přivedeno k sobě samému, znamená: k sobě jako k bytosti, která se může sama určovat a autentickým životním rozvrhem si odemykat svět a zároveň svou vlastní podstatu. To je onen ztracený a nyní znovu nalezený smysl bytí a také času, který Heidegger hledá.

Heideggerův další popis ožrejmuje klíčovou problematiku. Já si všímá, říká Heidegger, že to, co mu volání dává na srozuměnou, je vpravdě jen výrazem jeho vlastní podstaty. ${ }^{15} \mathrm{~A}$ to znamená, že v instanci volání vnímá svou vlastní podstatu, jež se mu nejprve musela jevit jako cizí, a potud se mu ukazovala v podobě volání přicházejícího zvnějšku. Proto může Heidegger říci: „Ve svědomí volá pobyt sebe sama." ${ }^{16}$

Nelze však vůbec nahlédnout, jak pobyt, jenž je ostatně nazýván také „Já“, může volání nejen vnímat, ale také chápat, že je volán on sám, že takř́íkajíc jde o jeho vlastní věc, k níž se má nyní vztahovat v modu sebeurčení, pokud již nedisponuje dispozicionálním praktickým

\footnotetext{
14 Tamt., str. 310.

15 Tamt., str. 312.

16 Tamt.
} 
sebevědomím, jež předchází všem konkrétním vztahům ke světu a jež je principem požadovaného sebeurčení. Na to však není v Heideggerově popisu pamatováno žádným myšlenkovým konceptem. A ani na to pamatováno být nemůže, protože způsob bytí Já je definován „bytím ve světě“, jak Heidegger v této souvislosti ještě jednou emfaticky zdůrazn̆uje, ${ }^{17}$ a nikoli jako Já, které je s to distancovat se od všech vztahů ke světu a vztáhnout se pouze ke své kompetenci sebeurčování. Toto původní praktické sebevědomí není částí „,bytí ve světě“, naopak lze říci, že je třeba je situovat mimo jeho hranici.

Pohlédneme-li z této perspektivy ještě jednou zpět na Heideggerovu teorii časovosti a na tezi, že jednota tří dimenzí časovosti má představovat fundament pro způsob, jak se pobyt realizuje $v$ modu autenticity, musí být koncept původního praktického sebevědomí vnesen také do teorie časovosti. To znamená, že nemůže být momentem ve struktuře časovosti v Heideggerově smyslu právě proto, že je poslední podmínkou, za níž je realizace vlastního životního rozvrhu v čase vůbec možná. Tak mu musí přináležet pozice, která logicky předchází tomu, co Heidegger nazývá časovostí. Je-li tomu tak, pak ústřední teze Bytí a času, že časovost je posledním základem, z něhož lze pochopit možnost existence pobytu, není udržitelná. Posledním základem je původní praktické Já. ${ }^{18}$

\section{K Husserlově teorii vnitřního časového vědomí}

Na základě Husserlových okrajových poznámek k Heideggerovu Byti a času jsou pochopitelné problémy s porozuměním, s nimiž byl Husserl konfrontován při své intenzivní četbě, jíž věnoval - lépe by bylo říci obětoval - zejména letní měsíce roku 1929 strávené u Comského jezera. K Heideggerovu zdůvodnění nutnosti existenciální analytiky pobytu si iritován a s jistou hořkostí poznamenal:

„Heidegger transponuje či transversuje konstitutivně fenomenologické vysvětlení všech regionů jsoucího... do antropologie; celá

17 Tamt.

18 J. Stolzenberg, Martin Heideggers Sein und Zeit, in: R. Brandt - T. Sturm (vyd.), Klassische Werke der Philosophie. Von Aristoteles bis Habermas, Leipzig 2002, str. 257-284. A dále týž, Martin Heidegger liest Fichte, in: H. Seubert (vyd.), Heideggers Zwiegespräch mit dem deutschen Idealismus, Köln - Weimar - Wien 2003, str. 77-91. 
problematika je přenesením, egu odpovídá pobyt etc. Přitom se vše stává hlubokomyslně nejasným a filosoficky to ztrácí svou hodnotu. “19

Otázku, zda je Husserlova diagnóza a kritika oprávněná, zde nemůžeme probírat. Nezávisle na tom se ve vztahu k teorii autenticity jeví plausibilní teze, že především Heideggerem formulovaná jednotnost souvislosti tř̌́ dimenzí časovosti je proměnou či přizpůsobením základního ustrojení vnitřního časového vědomí, jak je Husserl popsal ve svých raných přednáškách.

Husserl popisuje strukturu vnitřního časového vědomí, jak známo, jako jednotu souvislosti momentů praimprese, retence a protence, která je imanentní vědomí. Připomeňme zde pouze, že praimprese se vztahuje $\mathrm{k}$ počátku, k prvnímu časovému bodu trvání například vnímaného tónu, k němuž můžeme odkazovat deiktickým výrazem „nyni““. Retence naproti tomu označuje tu fenomenální skutečnost, že se vjem obsažený v konkrétním přítomném bodě neustále proměňuje tak, že každé vnímané „nyni““ se kontinuálně modifikuje v „právě bylo“. Přitom je rozhodující, že tyto fáze nevystupují z pole vědomí, nýbrž jakožto fáze dříve aktuálně vnímaného tónu jsou podržovány v „ohonu komety retencí“ ${ }^{20}$ jak to Husserl vyjadřuje. Toto podržování nelze proto ani popsat jako vzpomínku, jež reprodukuje završený prožitek; spíše se jedná o př́itomnost bezprostředně uplynulých fází tónového kontinua $\mathrm{v}$ aktuálním vjemovém vědomí. S tím koreluje protence, očekávání nadcházejících fází trvání vnímaného objektu. Tímto způsobem se buduje vědomí trvání identického objektu vnímání - např́íklad tónu v jeho trvání.

Na místo Husserlovy teorie vnímání identického imanentního časového objektu v jeho trvání na straně vnímajícího subjektu vstupuje v Heideggerově existenciální fenomenologii časovost jako základní ustrojení konkrétní subjektivity. Heidegger sdílí s Husserlem distanci vůči tomu, co Husserl nazývá objektivním časem či časem světa a Heidegger vulgárním časem, časem, s nímž každodenně zacházíme. Spolu s Husserlem zdůrazňuje Heidegger zejména jednotnou souvislost - existenciálně interpretovaného - minulého $s$ aktuálně přítomným a budoucím. Na rozdíl od Husserla chápe Heidegger tento jednotný smysl z trojitě členěného sebevztahu, jenž definuje „vlastní“ způsob existence Já.

19 E. Husserl, Randbemerkungen Husserls zu Heideggers Sein und Zeit und Kant und das Problem der Metaphysik, in: Husserl Studies, 11, 1994, str. 13.

20 E. Husserl, Vorlesungen zur Phänomenologie des inneren Zeitbewußtseins. Mit den Texten aus der Erstausgabe und dem Nachlaß, vyd. R. Bernet, Hamburg 2013, str. 328. 
Také nelze přehlédnout, že důraz, s nímž Heidegger prohlašuje dimenzi časovosti za poslední základ, z něhož je teprve možno dostatečně pochopit ,původní jednotu struktury starosti““, ${ }^{21}$ má svůj model v Husserlově neméně důrazném poukazu v Idejích, že čas je tím ,posledním a pravým absolutnem“, jež leží v základu veškerému vědomému životu a prožívání jakožto „,autonomní oblast problémů““.22 Podobné stopy Heideggerovy četby Husserla, jež mimo jiné, jak předpokládáme, zavedly Heideggera na jeho vlastní cestu, jsou v Bytí a času zahlazeny.

Naproti tomu je zřejmé, že Husserlův vztah časového prožívání k čistému Já, který Husserl zavedl ve svých pozdních zkoumáních, jež byly Heideggerovi známé, Heidegger do své vlastní koncepce časovosti nepřejal, a to proto, že, jak jsme již zmínili, fenomén „bytí ve světě“ takový vztah podle Heideggera vůbec neobsahuje. Vyjdeme-li však z toho, že Heideggerova teorie autenticity existence a spolu s ní teorie časovosti mají svůj fundament v onom původním praktickém sebevědomí, protože bez něho nelze dostatečně pochopit teorii svědomí a jí zdůvodněnou řeč o autenticitě a nejvlastnějš́m ,,moci být “, pak se zdá být ze strukturálních důvodů nasnadě vyjasnit si Husserlovu koncepci čistého Já v kontextu jeho teorie času z jeho vlastní perspektivy, abychom se odsud ještě jednou vrátili k Heideggerovi.

\section{Husserlova teorie čistého Já v kontextu jeho teorie času}

Vzhledem ke skutečnosti, že v Idejích zavedl Husserl koncepci čistého Já jako invariantního centra všech jeho prožitků a intencionálních vztahů, ${ }^{23}$ je snadno pochopitelná role, jakou hraje toto Já v kontextu známých teoretických úvah o času: jakožto čisté Já a identické centrum svých časových prožitků nemůže samo být částí prožitkového proudu. Čisté Já je třeba chápat spíše jen jako hranici proudu prožitků. Přesně tuto pozici zastává Husserl v tzv. bernauských rukopisech z let 1917/1918. „Já“ je tím aspektem subjektivního života, rozvádí zde Husserl, který „,nemáme v prožitkovém proudu“, nýbrž je ,identickým centrem, pólem, k němuž je vztažen celkový obsah prožitkového proudu“ “. ${ }^{24}$ Protože samo není

\footnotetext{
21 M. Heidegger, Bytí a čas, str. 329.

22 E. Husserl, Ideje k čisté fenomenologii a fenomenologické filosofii, str. 168.

23 Srv. tamt., str. 117 n., 165 n. aj.

24 E. Husserl, Die Bernauer Manuskripte über das Zeitbewusstsein (1917/1918), vyd. R. Bernet - D. Lohmar, Dordrecht - Boston - London 2001, str. 277.
} 
částí časově rozlehlého vjemu, je, zdůrazňuje zde Husserl, pochopitelné „jen jako hranice toho, co v časovém toku uplývá““ ${ }^{25}$

Zdá se, že Husserlova raná teorie vnitřního časového vědomí obsahuje mj. problém, na který věcně reaguje přijetím čistého Já. Tento problém vyvstane tehdy, když si položíme otázku, jak je možné vědomí podržování vjemového prožitku, jež má vykonávat retence. Husserlovou tezí totiž je, že retence, do níž přechází praimprese, je sama nějakým nyní aktuálním vědomím, „něčím aktuálně existujícím““. ${ }^{26}$ Není jasné, co se tím míní. Nemůže se mínit, že vědomí o tom, že se retence vyskytuje, patří jako část ještě k praimpresi, která je dána nyní. Husserl toto nemůže mínit proto, že praimprese je hranicí retence, a retence tak nemůže být dána a vědoma zároveň s praimpresí. Jak si ale potom máme vysvětlit, že existuje vědomí o tom, že retence nereprezentuje aktuální tón, nýbrž právě uplynulý tón? Je-li retencionální vědomí samo opět novým nyní, něčím „aktuálně existujícím“, pak nelze nahlédnout, jak může být splněna podmínka intencionálního vztahu, v němž je zahrnut požadovaný rozdíl aktuálně vnímaného a právě uplynulého jakožto obsah, o němž existuje vědomí. Nelze to nahlédnout proto, že retencionální vědomí samo od sebe, právě proto, že reprezentuje něco, co právě uplynulo, se nijak nevztahuje k praimpresi, která mu předchází. Pak ho ale ani nelze pochopit jako vědomí právě uplynulého tónu. $Z$ toho plyne, že tímto způsobem nemůže vznikat jednotné vědomí časového toku a trvání v něm vnímaného objektu.

Vysvětlení takového - ve vztahu k vjemovým fázím - jednotného vědomí o trvání nějakého objektu má zajistit předpoklad čistého Já. Rekurs k pozici čistého Já je ospravedlněn Husserlovou metodou fenomenologické redukce, tj. převedením všech platnostních nároků na jejich původ v transcendentální subjektivitě, jak zní Husserlovo označení. To zde nebudeme dál sledovat. Rozhodující je funkce, která je tomuto čistému Já přiznána. V této souvislosti jsou klíčové dva texty Bernauských rukopisů o časovém vědomí, které vydavatelé označují čísly 14 a 15. Jejich název zní: „Můj prožitkový proud a Já“ a „Časový vztah čistého Já““. ${ }^{27}$ Čisté Já zde plní funkci základu vědomí jednoty, a to znamená, že je základem

25 Tamt., str. 287. Zvýraznil J. S. Eduard Marbach rekonstruoval v rámci göttingenské konference konané v listopadu 2009 genezi Husserlovy ideje čistého Já během jeho göttingenského období z teorie intersubjektivity.

26 E. Husserl, Vorlesungen zur Phänomenologie des inneren Zeitbewußtseins, str. 32 .

27 E. Husserl, Die Bernauer Manuskripte über das Zeitbewusstsein, str. 274-280, 281-288. 
vědomí rozlišení $a$ vztahu praimpresionálního a retencionálního vědomí. Čisté Já je schopno plnit tuto funkci díky tomu, že časově odlišné mody vnímání nejen konstituuje, nýbrž zároveň je vztahuje k sobě tak, že tím získává vědomí průběžné identity sebe sama ve vztahu k časově odlišným modům vnímání a jejich předmětům. Tím, že toto činí, udržuje čisté Já kontinuálně přecházející vztah k diferentním modům vnímání a jim přiřazeným časovým místům i vztah $\mathrm{k}$ sobě samému. Formulováno jinak: Já vnímá časově odlišné způsoby danosti nějakého předmětu a vztahuje je k sobě navzájem díky tomu, že je vztahuje k sobě jako $\mathrm{k}$,identickému funkcionálnímu centru“, jež je od nich odlišné, ${ }^{28}$ jak to Husserl vyjadřuje. Můžeme říct, že nyní, $\mathrm{v} \Delta \mathrm{t}_{1}$, vnímám tón $a$; nyní v $\Delta \mathrm{t}_{2}$, vnímám, jakožto totéž Já, tón $b$ a tón $a$ jako právě uplynulý; nyní $\mathrm{v} \Delta \mathrm{t}_{3}$, vnímám, jakožto totéž Já, tón $c$ a z hlediska časových míst diferentní tóny $a$ a $b$ jako právě uplynulé. Tím, že se Já takto chová a že - jak poznamenává Husserl - „se aktivně zaměřuje na konstituované, činně se na něm podílí“, ${ }^{29}$ vzniká mu nejen stále nová subjektivně-časová skutečnost, ale je s tím navíc spojena reflexe na straně Já, jež se v průběhu kontinuálního přecházení a podržování toho právě uplynulého jakožto právě uplynulého vnímá jako numericky ,identické funkcionální centrum, jako to vykonávající všech těchto výkonư““. ${ }^{30}$ Tomuto sebevědomí odpovídá výpověd’: „Já to konám“ - „a zde“, říká Husserl, „narážíme na pól, na něco identického, co samo není časové““. ${ }^{31}$

Husserl zjevně naráží na Kantovu teorii transcendentálního Já v dedukci kategorií, když vysvětluje, že „toto čisté identické Já je ,stojícím a přetrvávajícím“ Já“, jež „na rozdíl od prožitku samo nevzniká a nezaniká“, 32 a že stejně jako Kantovo Já je „,co do obsahu zcela prázdnou představou“, která ani pro Husserla „nemá v čase žádný obsah, nic odlišného, a nic stejného, nic názorového, vnímatelného, prožívatelného“. ${ }^{33}$ A konečně zde čteme i další Kantovi blízkou tezi, ${ }^{34}$ že toto Já se sobě může stát předmětem a může si být vědomo identity sebe sama ve vztahu ke svým vjemům jen tehdy, když má před očima své akty a časově konstituující funkce, jimiž se vztahuje ke svým prožitkům, a právě v tom se uchovává

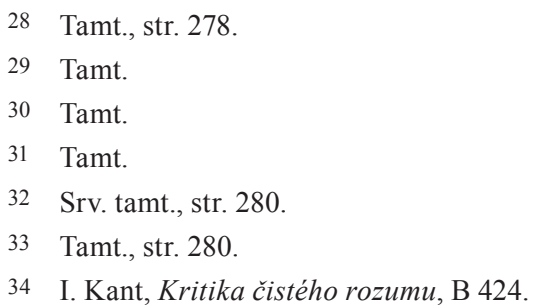


jako numericky identické Já, takže je „uchopitelné jen reflexivně a jen zpětně “. ${ }^{35}$ Přetrvává však otázka, jak lze přesněji pochopit časově teoretický status takto popsaného Já, má-li o něm platit, že „samo není časové“.

$\mathrm{K}$ tomu lze poznamenat dvojí. Protože čisté Já samo není částí časově rozlehlého vjemu, je, jak ř́ká Husserl, pochopitelné ,jen jako hranice toho, co v časovém toku uplývá'“ ${ }^{36} \mathrm{O}$ tom jsme již mluvili. Nicméně tím není dostatečně charakterizován časovostní status. Zmíněná vysvětlení prozrazují, že Husserl se způsobem fungování čistého Já podává fenomenologickou interpretaci pojmu kontinua známého $\mathrm{z}$ aristotelské teorie času, a odtud získává fundament své teorie času. Kontinuum je, jak známo, definováno tím, že směruje do nekonečna a je neomezeně dělitelné; dále pak tím, že samo nesestává z částí, nýbrž lze je jen dělit. Pojem kontinua je tedy operativně-performativní pojem. Kontinuum se jako takové znázorňuje jen tehdy, je-li specifickým způsobem určeno, resp. děleno. Dělení odpovídá v naší souvislosti sukcese identifikovatelných časových míst. Tomu fenomenologicky odpovídá vjem retencionální modifikace. Na základě formy posloupnosti, jež je pro ni charakteristická a jejímž definitorním znakem je diference časových míst, odkazuje k základnímu kontinuu, jež se znázorňuje jako kontinuum teprve v médiu časového vnímání. Přesně v tom spočívá funkce čistého Já. Jak Husserl dále poznamenává, čisté Já je ,stále zde, neoddělitelné od prožitkového proudu a... nutně kontinuálně trvá skrze něj“. ${ }^{37}$ Sobě samému se však jeví a samo sebe uchopuje pouze tím, že ve vztahu ke svým v každé časové fázi se proměňujícím prožitkům, jež jako takové vnímá, uchovává samo sebe jako jednotně fungující numericky identické Já, jako „identitu formy““. ${ }^{38}$ Tak lze nyní říci, že čas a vjem času je formální podmínkou, za které vnímá čisté Já samo sebe pod popisem, jenž se týká jeho časového prožívání. Husserl tím rozvrhl teorii subjektivity, v níž je základní ustrojení subjektivity pochopeno jako časovost. Spočívá v tom, že Já se konkretizuje a vnímá v médiu jím samým konstituovaných forem uchopování času a jim odpovídajících předmětů. Já ,je jako sebe časujícíc ${ }^{\prime 39}$ - tato Husserlova věta vyjadřuje formálně jednotu sebevědomí a časovosti v Husserlově smyslu.

35 E. Husserl, Die Bernauer Manuskripte über das Zeitbewusstsein, str. 287.

36 Tamt.

37 Tamt., str. 280.

38 Tamt.

39 E. Husserl, Späte Texte über die Zeitkonstitution (1929-1934), Die C-Manuskripte (Husserliana-Materialien), VIII, New York 2006, str. 53. 


\section{Heidegger a Husserl o čase}

Na tomto pozadí je třeba se závěrem vrátit k Heideggerově teorii časovosti a autenticity existence. Jako výsledek analýzy Heideggerovy teorie autenticity lze podržet následující tezi: máme-li moci mluvit o rozhodnutí, rozhodnutí, jemuž leží v základu ,vhled pobytu do sebe sama“ ${ }^{40}$ jak vysvětluje Heidegger v přednáškách z letního semestru 1927, je třeba předpokládat vůči všem vztahům ke světu distancovaný sebevztah na straně toho, kdo se rozhoduje ke svému „nejvlastnějšímu moci být“.

O takovém sebevztahu, jímž je vyjádřen princip toho, co Heidegger nazývá nejvlastnějši ,,moci být“, platí vzhledem k teorii časovosti rovněž druhá teze: není částí časovosti, nýbrž jejím předpokladem. Lze však rríci ještě víc, a toto „víc“" se týká pojmu jednoty tří dimenzí časovosti. Tento pojem má funkcionální smysl. Vyjadřuje okolnost, že spolu jsou to formy, v nichž se Já pobytu ve svém životním rozvrhu, k němuž se rozhodlo, realizuje ve formě trojitě členěné sebevztaženosti. Já je společným referentem reflexivního zájmena „se“, které Heidegger užívá ve třech formulích časovosti „nechat sebe přicházet k sobě “ (auf sich zukommen), ,přicházet zpět k sobě“ (auf sich zurückkommen) a „být u sebe“ (bei sich sein). Já je tedy základem, z něhož je třeba vysvětlovat jejich jednotu.

Tyto formy časově interpretovaného sebevztahu se nyní realizují a konkretizují ve smyslu procesuality vždy určené odlišně podle časovostních modů. Společným referentem těchto procesuálně se realizujících forem sebevztahu však je a zůstává to Já, jež se, abychom ještě jednou užili Heideggerův výraz, rozhodlo ke svému nejvlastnějšímu „moci být" - a o němž ani nelze říci víc než toto. Ono samo je tedy „,co do obsahu zcela prázdné“. Svou konkretizaci získává pouze prostřednictvím jednání, která jsou mu otevřená $\mathrm{v}$ dané př́ítomnosti a která se snaží realizovat $\mathrm{v}$ popsaných procesuálních časovostních modech budoucnosti a vztahu k minulému. Pouze tímto způsobem získává konkrétní porozumění sobě samému, resp. tomu, co znamená „nejvlastnější moci být“.. Jakožto průběžná vztahová veličina leží tomuto celému procesu v základu ono původně praktické Já, jež se v distanci vůči všem vztahům ke světu rozhodlo pro sebe a k sobě.

Struktura tohoto vztahu mezi Já pobytu a jeho časově určenými konkretizacemi ukazuje vzhledem ke svému formálnímu ustrojení zjevné

40 M. Heidegger, Die Grundprobleme der Phänomenologie, vyd. F. W. von Herrmann, in: Gesamtausgabe, XXIV, Frankfurt a. M. 1975, str. 393. 
podobnosti se vzájemným funkcionálním vztahem podmíněnosti mezi oním čistým Já a různými formami jeho časového uchopení, v nichž se realizuje. Tento funkcionální vztah podmíněnosti leží v základu Husserlovy zralé teorie času, která, jak jsme ukázali, chápe subjektivitu samu jako časovost. Aniž bychom přehlíželi či marginalizovali systematické diference, v nichž se Heideggerova a Husserlova teorie liší, lze na základě provedených úvah snad přece jen říci, že krokem, jímž Husserl zavedl do teorie času koncept čistého Já, se souvislosti časovosti a subjektivity přiblížil o krok blíž než jeho ,nevěrný“ žák.

Přeložil Jindřich Karásek

ZUSAMMENFASSUNG

Anhand eines strukturanalytischen Vergleichs geht der Verfasser der Frage nach, auf welche Weise das Verhältnis von Subjektivität und Zeitlichkeit in Husserls und Heideggers Philosophie begründet wird. Die Struktur des Verhältnisses zwischen dem Selbst des Daseins und seinen zeitlich bestimmten Konkretionen, wie von Heidegger aufgefasst, weist hinsichtlich seiner formalen Verfassung Ähnlichkeiten auf mit dem wechselseitigen funktionalen Bedingungsverhältnis zwischen dem reinen Ich und den unterschiedlichen Formen seiner Zeiterfassung, das Husserls avancierter Zeittheorie zugrunde liegt. Aufgrund der Einführung des reinen Ich in die Theorie der Zeit ist es gerade Husserl, der dem Zusammenhang von Zeitlichkeit und Subjektivität letztlich einen Schritt nähergekommen ist als Heidegger.

SUMMARY

Based on a structural-analytical comparison, the author investigates the question of how the relation between subjectivity and temporality is grounded in Husserl's and Heidegger's philosophy. Due to its formal constitution, the structure of the relationship between the Self of the $D a$ sein and its temporally determined concretions, as conceived by Heidegger, shows similarities to the mutual functional relationship between the pure ego and the different forms of its temporal renditions, which underlies Husserl's advanced theory of time. Because of the introduction of the pure ego into the theory of time, it is Husserl who has come one step closer to the connection between temporality and subjectivity than Heidegger. 